\title{
Determining suitable locations for seed transfer under climate change: a global quantitative method
}

\author{
Kevin M. Potter • William W. Hargrove
}

Received: 2 November 2011/ Accepted: 22 March 2012/Published online: 5 April 2012

(C) Springer Science+Business Media B.V. 2012

\begin{abstract}
Changing climate conditions will complicate efforts to match seed sources with the environments to which they are best adapted. Tree species distributions may have to shift to match new environmental conditions, potentially requiring the establishment of some species entirely outside of their current distributions to thrive. Even within the portions of tree species ranges that remain generally suitable for the species, local populations may not be well-adapted to altered local conditions. To assist efforts to restore forests and to maximize forest productivity in the face of climate change, we developed a set of 30,000 quantitatively defined seed transfer "ecoregions" across the globe. Reflecting current and future conditions, these were created by combining global maps of potentially important environmental characteristics using a large-scale statistical clustering technique. This approach assigns every $4 \mathrm{~km}^{2}$ terrestrial raster cell into an ecoregion using nonhierarchical clustering of the cells in multivariate space based on 16 environmental variables. Two cells anywhere on the map with similar combinations of environmental characteristics are located near each other in this data space; cells are then classified into relatively homogeneous ecoregion clusters. Using two global circulation models and two emissions scenarios, we next mapped the predicted environmentally equivalent future locations of each ecoregion in 2050 and 2100. We further depicted areas of decreasing environmental similarity to given ecoregions, both in current time and under climate change. This approach could help minimize the risk that trees used for production, restoration, reforestation, and afforestation are maladapted to their planting sites.
\end{abstract}

Keywords Restoration - Conservation genetics - Quantitative ecoregions · Multivariate clustering $\cdot$ Seed sources $\cdot$ Human-assisted migration

\footnotetext{
K. M. Potter $(\bowtie)$

Department of Forestry and Environmental Resources, North Carolina State University, 3041 Cornwallis Road, Research Triangle Park, NC 27709, USA

e-mail: kpotter@ncsu.edu

W. W. Hargrove

Eastern Forest Environmental Risk Assessment Center (EFETAC), Southern Research Station, USDA

Forest Service, Asheville, NC 28804, USA
} 


\section{Introduction}

Climate change will likely complicate the practice and outcomes of ecological restoration efforts, including reforestation and afforestation, as future biophysical conditions shift from their current settings (Harris et al. 2006). Preliminary evidence suggests that tree species are already exhibiting changes in phenology and distribution in response to climate change (Parmesan and Yohe 2003; Woodall et al. 2009; Root et al. 2003). In light of these changes, it will be a significant challenge to match plant materials to the environments to which they will be best adapted.

The establishment of seed transfer zones and guidelines that account for climate change will be necessary to select seed sources optimally adapted to a future climate (Ying and Yanchuk 2006), as many plant populations may no longer be optimally adapted to local conditions (Kramer and Havens 2009; Rehfeldt et al. 2001). Forest geneticists have long recognized the importance of addressing the relationship between adaptive variation and the potential effects of climate change (Rehfeldt et al. 1999; Schmidtling 1994; Persson 1998). Recent innovative work has used climate change projections to predict the future locations of current seed transfer zones for commercially important conifer species (e.g., Rehfeldt and Jaquish 2010; Thomson et al. 2010). In these cases, the seed transfer zones were determined with data from common garden trials that allowed for the development of species-specific models relating adaptive genetic variation to geographic and climate variables (Ying and Yanchuk 2006). Such an approach is not practical or possible for many plant species, however, because resources for extensive genetic testing are often lacking (Vogel et al. 2005). As a result, data quantifying local adaptive variation exist for only a fraction of the tree species used in restoration, and even for those, studies address only a subset of populations (McKay et al. 2005). Therefore, for most species used in restoration projects, little is known of the spatial or ecological scale over which seed can be moved, and the boundaries are often a "best guess" in the absence of any real understanding of adaptive variation (Broadhurst et al. 2008).

Although less preferable than direct provenance growth tests, indirect geographic approaches utilizing biotic and abiotic variables may suggest where plant materials may be best adapted (Jones 2005). Seed transfer zones and guidelines may, for example, be defined based on geographic distance from a seed source, combined with climate and geomorphology (Vander Mijnsbrugge et al. 2010). In fact, before data were available from common-garden studies and genetic field trials, some of the first seed transfer zones for commercially important tree species were based primarily on local evaluations of differences in environment, climate, and vegetation, and included general restrictions on elevational transfer (Johnson et al. 2004).

Many seed-zone systems in practical use have been developed by evaluating available genetic information and then determining reasonable transfer guidelines or seed-zone delineations that usually track ecological regions (Hamann et al. 2011). In the absence of species-specific information about adaptive genetic variation, ecoregions might serve as potential seed transfer zones because they encompass geographic areas with similar geology, climate, vegetation, soils and hydrology (Miller et al. 2010). Recently, U.S. Environmental Protection Agency (EPA) level III ecoregions (Griffith et al. 2008) were determined not to be too large to serve as suitable seed transfer zones for herbaceous (Miller et al. 2010) and grass species used in grassland restoration (Wilson et al. 2008). EPA ecoregions were also found useful for sampling genetic diversity in a shrub species important for restoration (Horning et al. 2010). Genetic variation in lodgepole pine (Pinus contorta Dougl.) was found to follow biogeoclimatic ecosystem classification delineations 
in interior British Columbia (Pojar et al. 1987; Wu et al. 2005). As a result, biogeoclimatic ecoregions have been used determine seed selection guidelines in British Columbia (Ying and Yanchuk 2006). In other situations where information about adaptive variation was not available, ecoregion or ecoregion-like delineations have been used to guide seed transfer recommendations in Canada (Hamann et al. 2011), the United States (Vogel et al. 2005; Schmidtling 2001), and Europe (Malaval et al. 2010; Vander Mijnsbrugge et al. 2010).

The application of ecoregions to inform seed transfer is particularly useful for species for which little is known about adaptive genetic or molecular marker variation, or for which such information is missing across important parts of their ranges. The boundaries of ecoregion maps, however, are usually subjective and based on expert opinion (Jones 2005), and the borders of environmentally based seed zones are often arbitrary and may not reflect real genotypic differentiation (Vander Mijnsbrugge et al. 2010). Additionally, standard expert-derived ecoregion treatments do not account for fine-scale environmental variation, which can influence the distribution of adaptive variation within a species (Kramer and Havens 2009).

To address these concerns, we propose using quantitatively defined ecoregions, derived directly and entirely from climate, soils, and geomorphology data, to inform seed transfer decisions for species used in production, restoration, reforestation and afforestation. We describe a global set of 30,000 quantitatively defined ecoregions, determined at a relatively fine scale, which can be used to assist in seed transfer decision-making in the context of climate change. We also present examples of such applications for two eastern North American tree species of restoration interest.

These quantitative ecoregions were generated using the multivariate spatio-temporal clustering (MSTC) technique. MSTC-generated quantitative ecoregion maps have demonstrated good statistical fits with expert-defined ecoregion treatments (Hargrove et al. 2006), but are defined at a higher resolution $\left(4 \mathrm{~km}^{2}\right)$ and are able to account for changes over time in bioclimatic environmental variables (Hargrove and Hoffman 2005). The MSTC ecoregion technique can therefore address two seed transfer questions relating to climate change: (1) "If I have seeds from a given location, where can I plant them to best ensure the trees will be well-adapted in the future?" and (2) "If I want to plant trees in a given location and best ensure those trees will be well-adapted in the future, where do I go to collect the seeds?"

The case study species are longleaf pine (Pinus palustris Mill.) and flowering dogwood (Cornus florida L.). Longleaf pine is strongly associated with a once-widespread savanna ecosystem in the Southeastern United States that was reduced by $95 \%$ as a result of the long-term disruption of historical fire regimes coupled with land conversion and other anthropogenic factors (Van Lear et al. 2005; Gilliam and Platt 2006). Restoration and management of these ecosystems is critical, particularly at a time of rapid environmental change and loss of habitat (Gilliam and Platt 2006). Flowering dogwood, a common understory tree species, has been severely impacted by dogwood anthracnose, a fungal disease (Holzmueller et al. 2006). Infected stands have experienced high mortality rates and reduced regeneration, suggesting the species may be eliminated in many locations (Carr and Banas 2000; Williams and Moriarity 1999).

\section{Materials and methods}

We used multivariate spatio-temporal clustering (MSTC) (Hargrove and Hoffman 2005) to develop a set of 30,000 seed transfer "ecoregions" across the globe. MSTC employs non- 
hierarchical clustering of raster cells from a geographic information system (GIS) digital map to classify the cells into categories. It uses the standardized values of each environmental condition for every raster cell as a set of coordinates that together specify a position for that cell in a data space having a separate dimension for each of the environmental characteristics. Two cells from anywhere in the map with similar combinations of environmental characteristics will be located near each other in this data space. Their proximity and relative positions in data space will quantitatively reflect their environmental similarities, allowing these cells to be classified into groups or "ecoregions" with other cells possessing similar environmental conditions; each ecoregion contains a roughly equal amount of multivariate environmental heterogeneity (Hargrove and Hoffman 2005; Hoffman et al. 2005).

MSTC can recognize and track the same clustered combination of environmental conditions at any location or date based on multiple future climatic forecasts. It has therefore been used to predict global shifts in environmental conditions, allowing for the identification of potential climatic refugia (Saxon et al. 2005; Baker et al. 2010), and for the forecasting of suitable habitat conditions for species under differing global circulation models and emissions scenarios (Potter et al. 2010; Hargrove and Hoffman 2005). For this study, we assigned every $4 \mathrm{~km}^{2}(1.25 \mathrm{arcmin})$ cell on the terrestrial surface of the earth into one of 30,000 seed transfer ecoregions based on 16 bioclimatic (Hijmans et al. 2005), edaphic (Global Soil Data Task Group 2000), and topographic (Moore et al. 1991) environmental variables (Table 1). Additional information about variables included in MSTC analyses is provided by Saxon et al. (2005) and Baker et al. (2010). These variables play an

Table 1 Sixteen spatial environmental variables, spatially distributed at a resolution of $4 \mathrm{~km}^{2}$, used by the multivariate spatio-temporal clustering (MSTC) technique to define 30,000 quantitative global ecoregions

Category Spatial environmental variable

(A) Climatic variables

(1) Mean temperature in the coldest quarter $\left({ }^{\circ} \mathrm{C}\right)$

(2) Mean temperature in the warmest quarter $\left({ }^{\circ} \mathrm{C}\right)$

(3) Mean diurnal temperature range $\left({ }^{\circ} \mathrm{C}\right)$

(4) Annual biotemperature (sum of monthly mean temperature where mean $\geq 5{ }^{\circ} \mathrm{C}$ )

(5) Mean in the driest quarter ( $\mathrm{mm})$

(6) Mean in the wettest quarter ( $\mathrm{mm})$

(7) Mean in the warmest quarter ( $\mathrm{mm})$

(8) Mean in the coldest quarter ( $\mathrm{mm}$ )

(9) Precipitation/potential evapotranspiration

(10) Growing season (number of consecutive months with mean $\geq 5{ }^{\circ} \mathrm{C}$ )

$\begin{array}{ll}\text { (B) Edaphic variables } & \text { (1) Profile available water capacity (mm) }\end{array}$

(2) Soil bulk density $\left(\mathrm{g} / \mathrm{cm}^{3}\right)$

(3) Total soil nitrogen $\left(\mathrm{g} / \mathrm{m}^{2}\right)$

(4) Total soil carbon $\left(\mathrm{g} / \mathrm{m}^{2}\right)$

(C) Topographic (1) Compound topographic index (relative wetness)

variables $^{3}$ (2) Annual potential solar insolation $\left(\mathrm{kW} / \mathrm{m}^{2}\right)$

Data were custom downscaled from the sources listed

${ }^{1}$ http://www.worldclim.org (Hijmans et al. 2005)

2 IGBP-DIS: http://daac.ornl.gov/SOILS/guides/igbp-surfaces.html (Global Soil Data Task Group 2000)

${ }^{3}$ http://eros.usgs.gov (Moore et al. 1991) 
important role in the geographic distribution of plants across large areas (Lugo et al. 1999; Neilson 1995; Prentice et al. 1992); such broad-scale environmental factors have been associated with adaptive genetic variation across the range of plant species (O'Brien et al. 2007; Manel et al. 2010). While the method allows for the differential weighting of environmental variables, we gave them equal weight because our objective was to develop general seed transfer ecoregions for species about which little or no genecological information is available. Users of MSTC can specify how many ecoregions to generate, from a few large, coarsely defined ecoregions to many small, finely resolved ecoregions. We opted here to generate a larger number of seed transfer ecoregions, with each having a relatively small amount of environmental heterogeneity.

We used MSTC to determine the environmentally equivalent future location of each current seed zone in 2050 and 2100 for combinations of the Hadley and Parallel Climate Model global circulation models (GCMs) with the B1 (integrated, more ecologically friendly world) and A1FI (integrated, fossil-fuel intensive world) IPCC emissions scenarios. Maps of these quantitatively defined ecoregions are available, for current conditions and for 2050 and 2100 under the GCM/emissions scenario combinations, at http://www.geobabble.org/ hnw/global/seedzones. For this paper, we report our speciesspecific results only for a single GCM/emissions scenario combination for 2050 (Hadley B1), since our emphasis is to describe and illustrate this approach rather than to present a range of potential climate change effects.

This approach assumes that plants are optimally adapted to the environmental conditions present in their current locations. While this has been found to generally be the case for forest tree species (Johnson et al. 2004), there are exceptions (e.g., Wu and Ying 2004; Mangold and Libby 1978). Additionally, under some GCM/emissions scenario combinations, it may be possible that no locations contain the set of environmental conditions equivalent to those present in an ecoregion in current time (Fitzpatrick and Hargrove 2009). In this situation, no equivalent locations for that existing ecoregion will be predicted in the future maps (Hargrove and Hoffman 2003, 2005), although other future locations may be denoted as having environmental conditions that are similar to the original ecoregion.

Tree occurrence data

MSTC allows for the climate change projection tracking of quantitative ecoregions from across or from anywhere within the distribution of any species after selecting those ecoregions based on occurrence information. To select the quantitative ecoregions serving as seed transfer zones for our two study species, we used georeferenced species occurrence data available from the USDA Forest Service Forest Inventory and Analysis (FIA) program (United States Department of Agriculture Forest Service 2008). FIA maintains a system of approximately 125,000 fixed-area (approximately 0.067 hectares) inventory plots across the 48 conterminous United States and southeastern Alaska, with a plot intensity of approximately one for every 2,428 ha of land (Smith 2002). For longleaf pine, which is a relatively large tree species (Boyer 1990), an FIA plot was used as a training location if it contained at least one tree greater than $25.4 \mathrm{~cm}$ dbh or $9.14 \mathrm{~m}$ in height. A total of 1,525 FIA plots were used as longleaf pine training points (Fig. 1a). Because flowering dogwood is a smaller understory species (McLemore 1990), we selected as training locations the 4,301 FIA plots that contained a flowering dogwood stem at least $12.7 \mathrm{~cm}$ dbh or $6.1 \mathrm{~m}$ in height (Fig. 1b). To avoid overtraining the results because of relative differences in local species abundance, a quantitative ecoregion was selected as a longleaf pine seed transfer 
(a)

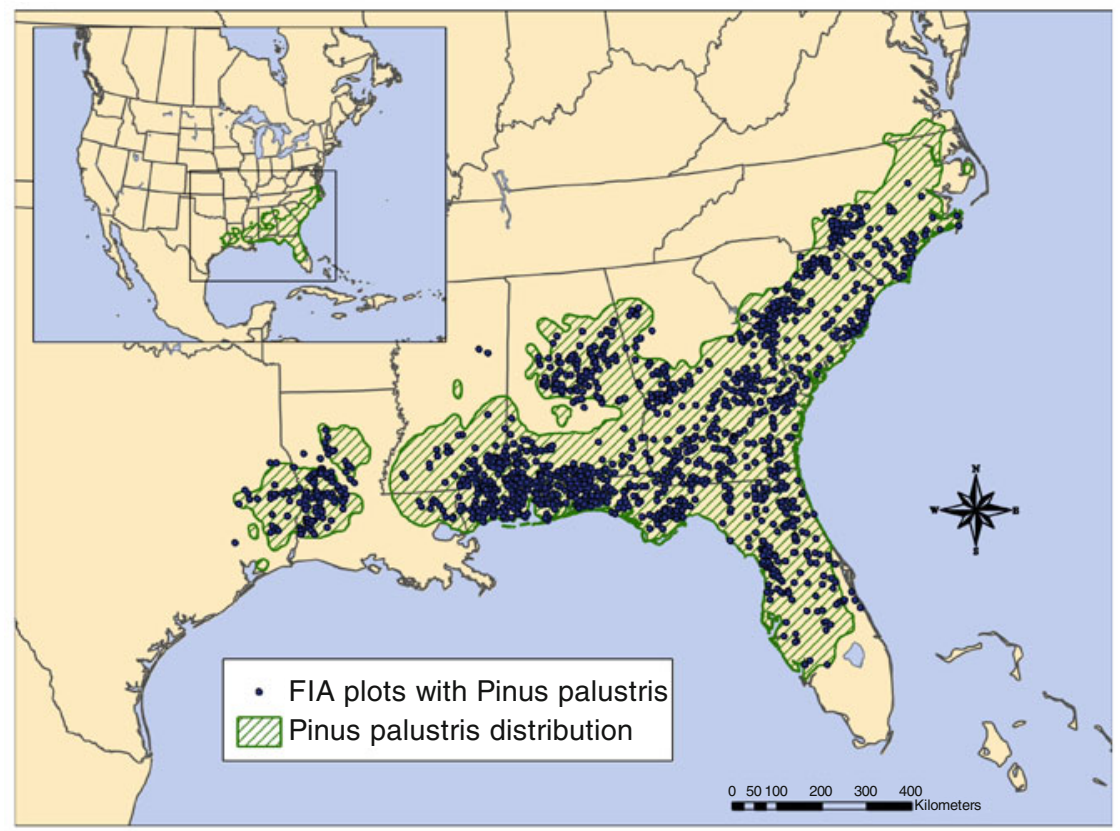

(b)

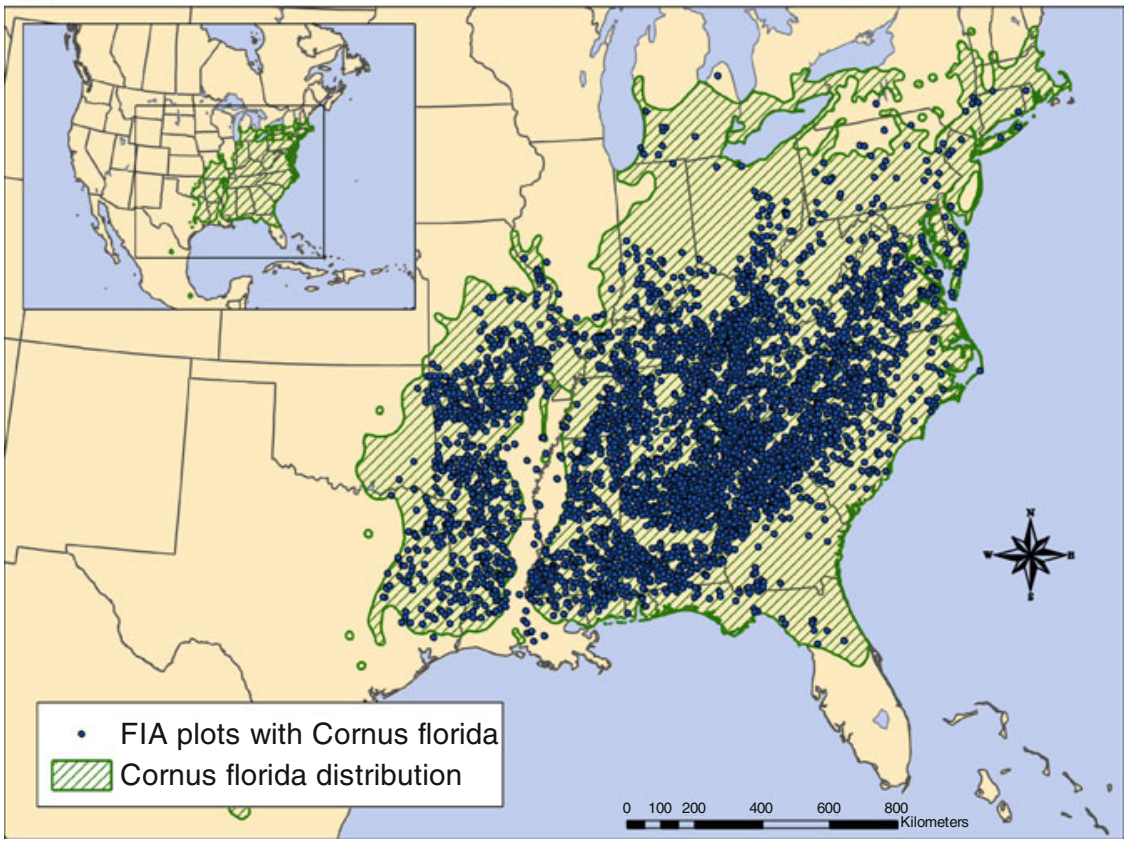

Fig. 1 Forest Inventory and Analysis (FIA) plots used as Multivariate Spatio-Temporal Clustering (MSTC) occurrence data for a longleaf pine (Pinus palustris) and b flowering dogwood (Cornus florida). The plot locations are approximate 
zone if it included three or more longleaf FIA plots, while an ecoregion was selected as a flowering dogwood seed transfer zone if it included four or more dogwood FIA plots.

\section{Seed zone forward and reverse projections}

We generated two sets of climate change projection maps for longleaf pine and flowering dogwood, both assuming the Hadley B1 GCM/emissions scenario combination for 2050. (1) The first set of maps answers the question "If I have seeds from a given location, where can I plant them to best ensure the trees will be well-adapted in the future?" These "forward projections" identify, for a given current seed transfer ecoregion, locations expected in the future to have equivalent environmental conditions. Assuming that planting stock is adapted to current location conditions, such information would be useful in guiding the proper deployment of seed of known provenance for a wide variety of objectives, including the establishment of commercial plantations or ex situ gene conservation plantings. (2) The second set of maps answers the question, "If I want to plant trees in a given location and best ensure those trees will be well-adapted in the future, where do I go to collect the seeds?" Each of these "reverse projection" maps identify, for a given restoration or reforestation site, the current seed transfer ecoregion which possesses environmental conditions most similar to the future habitat conditions projected in 2050 for the restoration or reforestation site. Assuming again that the planting stock is adapted to the current conditions, this identified ecoregion could, therefore, serve as a source of plant materials that offer the best chance that the species will persist on the site in the future. These maps are analogous to "focal point seed zones," in which an individual site to be reforested becomes the focal point, and a unique seed zone is established for that site, with a goal of identifying sources of seeds that are best adapted to the focal site (Parker 1992; Crowe and Parker 2005).

The forward and reverse projection maps display areas of decreasing environmental similarity to a focal site, whether for a seed source location in current time, or for a planting location for which we need the best-adapted plant material under climate change. This is possible because MSTC allows for the quantification and display of similarity among ecoregions. Similarity to a given ecoregion, defined as the Euclidean distance in data space between the centroids of two ecoregion clusters, can be displayed on a map as a grayscale ramp, with cells belonging to ecoregions more similar to the target ecoregion given darker colors, while those belonging to less similar ecoregions are given lighter colors. The assumption is that equal standardized changes in any environmental variable are equivalent in terms of the changes they would produce in environmental suitability for the species; while not likely to be true, this assumption is probably reasonable in the absence of genetic information.

This is conceptually consistent with the "floating principle" of seed transfer, which allows the movement of plant materials beyond zone boundaries as long as they are within their adaptive limit (Ying and Yanchuk 2006). It also reflects the fact that variation in species is often continuous across the landscape rather than ecotypic (Johnson et al. 2004; Jones 2005), and allows users to determine the appropriate thresholds of environmental similarity when assessing the suitability of seed for a given location and when faced with a scarcity of data about the environmental variables that drive natural selection for a species. The MSTC seed transfer ecoregion similarity maps therefore provide a spatial assessment of the risk of seed transfer beyond the zone within which the plant is most likely to be adapted to the environmental conditions, either in current or future time. The degree of risk associated with a given level of dissimilarity with the target ecoregion will depend, in part, 
on whether a species of interest is a generalist or a specialist (Johnson et al. 2004), or primarily outcrossing or inbreeding (Hufford and Mazer 2003).

\section{Results}

Longleaf pine ecoregions

For longleaf pine, 89 current ecoregions were intersected by at least three of the 1,525 FIA training locations. These ecoregions fit fairly closely with the extent of the species as determined by Little (1971) (Fig. 2a). When projected to 2050 under the Hadley global circulation model, B1 scenario, several of these ecoregions fragment and move north beyond the existing range of the species, while others remain relatively unchanged (Fig. 2b). Specifically, ecoregions immediately adjacent to the Gulf of Mexico or in the Florida peninsula are projected to change very little, while ecoregions in the western and central portions of the existing range fragment and shift north, leaving areas not expected to remain suitable for longleaf pine. The northeastern part of the existing distribution, meanwhile, is expected to remain suitable for the species, but the seed transfer ecoregions are generally expected to shift northward.

\section{Flowering dogwood ecoregions}

For flowering dogwood, 164 ecoregions were intersected by at least four of the 4,301 FIA training plots for the species. These ecoregions cover much of the flowering dogwood range, as defined by Little (1971) (Fig. 3a), except in the northern and southeastern portions of the distribution, where few if any FIA plots contained flowering dogwood (Fig. 1b). Few ecoregions appear unchanged when projected to 2050 under the Hadley B1 GCM/scenario combination (Fig. 3b). While previously unsuitable northern portions of the current range are predicted to become suitable, large areas in the western and southern extents of the current distribution may no longer be suitable for flowering dogwood. Several ecoregions are projected to move generally north, or to decrease in extent.

\section{Forward ecoregion projections}

The MSTC seed transfer ecoregion approach allows users who have seed or other plant material from a given location to identify areas where they can plant that material to best ensure the trees will be well adapted to predict future conditions. ("If I have seeds from this location now, where do I plant them for the future?") Specifically, it is possible to track the movement of a given ecoregion in current time to the locations expected to possess the equivalent environmental conditions in the future, based on a specific GCM/ emissions scenario combination. Additionally, it is possible to identify future areas with decreasing degrees of expected environmental similarity to the seed source in current time.

For longleaf pine, we identified areas of future potential adaptability for trees from an example current ecoregion located in the western part of the species' distribution in central Mississippi and Alabama (Fig. 4a, inset). Areas of future environmental equivalence to the source ecoregion, for Hadley B1 in 2050, were expected to occur to the northeast of the ecoregion in northern Alabama and Georgia and eastern Tennessee (Fig. 4a). Non-equivalent areas with high environmental similarity were projected to exist to the south of the 
(a)

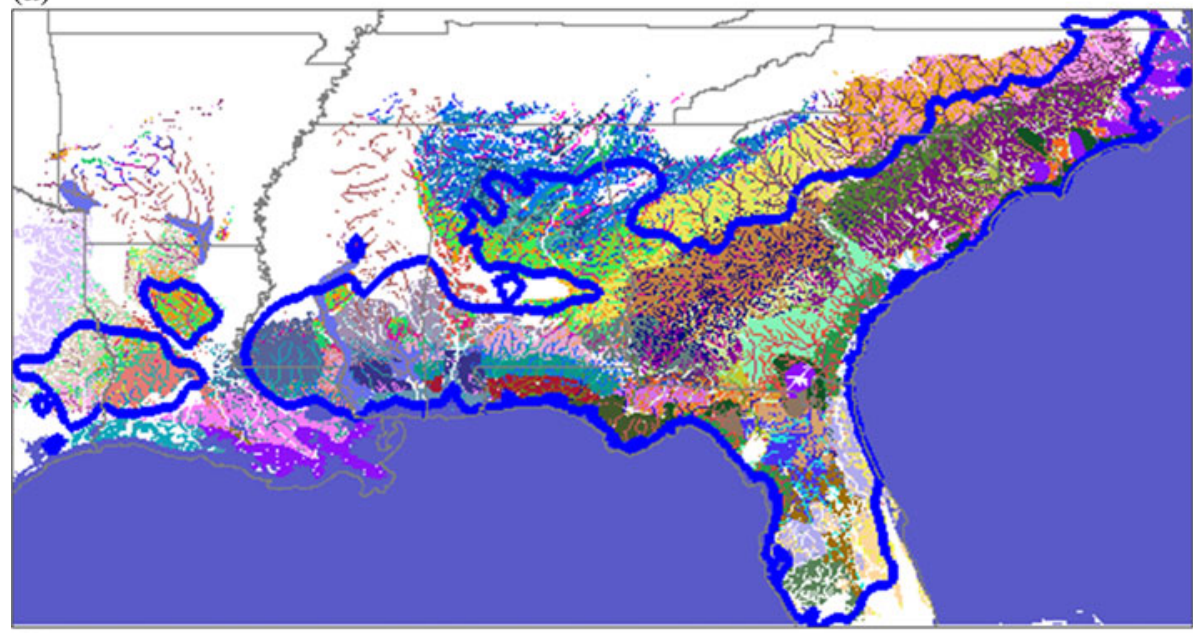

(b)

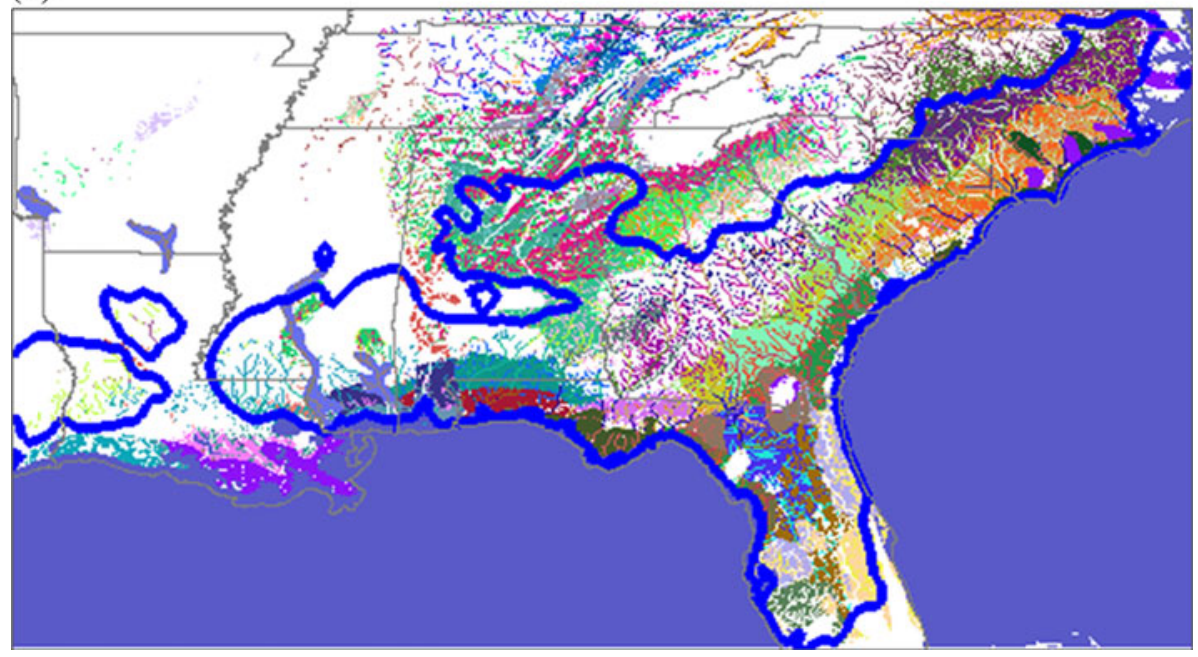

Fig. 2 Quantitative ecoregions selected as seed transfer zones for longleaf pine in a current time and b 2050 under the Hadley global circulation model, B1 emissions scenario

source ecoregion in southern Louisiana, Mississippi and Alabama. For flowering dogwood, we repeated this analysis for an example ecoregion currently existing in North Carolina and South Carolina (Fig. 4b inset). In 2050, environmentally equivalent areas were projected to move north into Virginia and west into Tennessee; areas throughout the southeastern United States and in western Pennsylvania were projected to be environmentally similar, but not identical, to the current conditions of the source ecoregion (Fig. 4b).

Reverse ecoregion projections

The MSTC seed transfer zone approach also allows users with a given planting location to identify potential seed sources from which to collect plant material most likely to be 
(a)

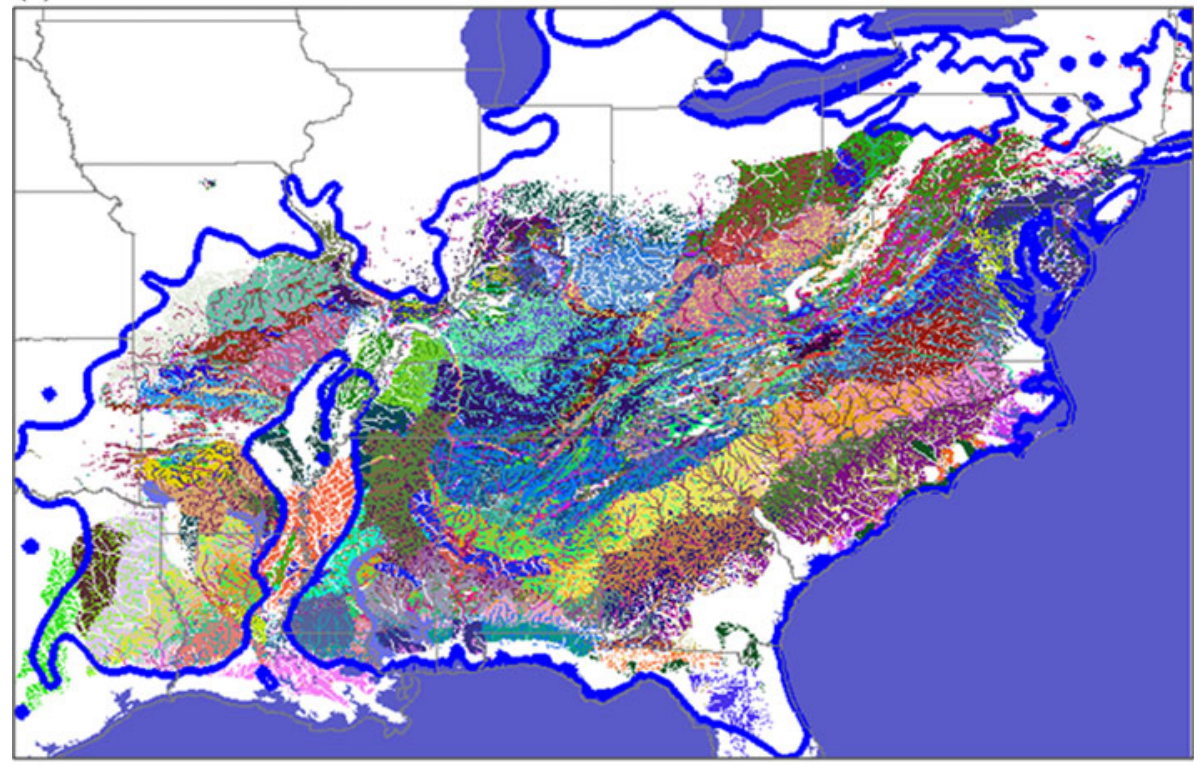

(b)

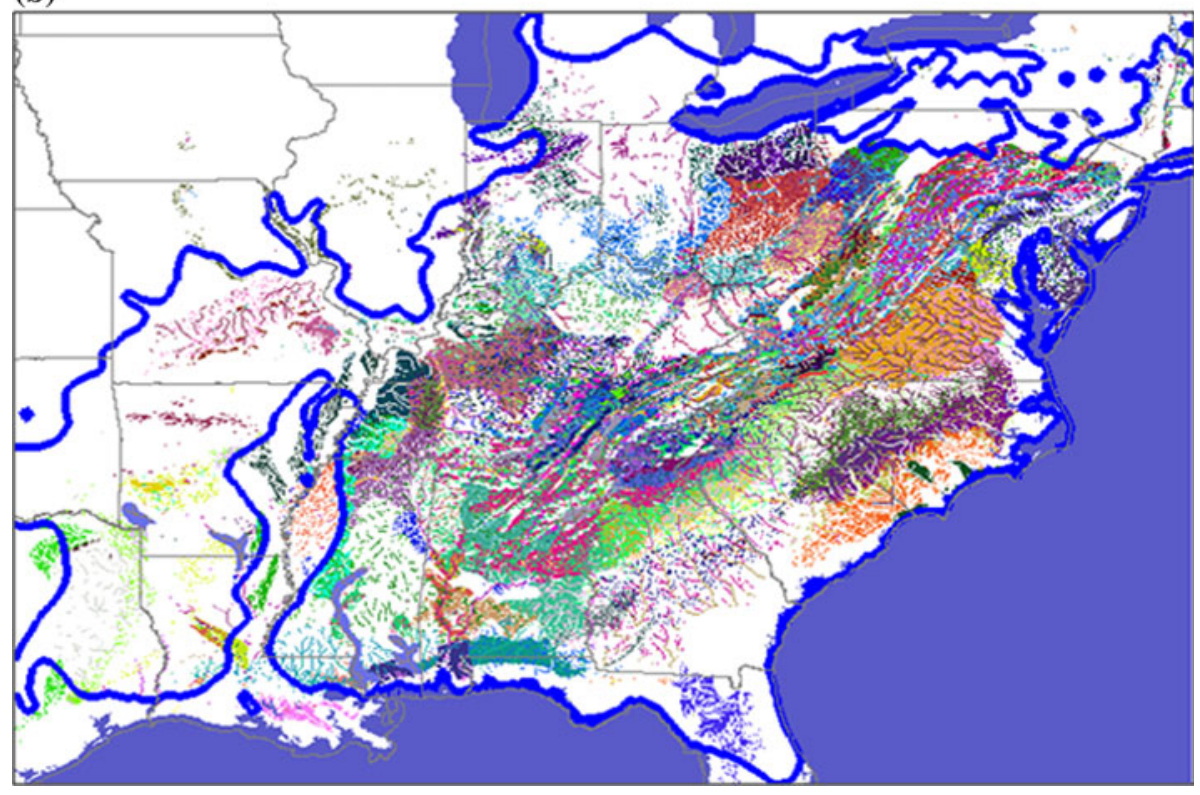

Fig. 3 Quantitative ecoregions selected as seed transfer zones for flowering dogwood in a current time and b 2050 under the Hadley global circulation model, B1 emissions scenario

well-adapted to the future environmental conditions of the planting location. ("If I want to plant trees here for the future, where do I go now to get the seeds?") Specifically, it is possible to take a projected future ecoregion, given a GCM and emissions scenario, and determine locations in current time possessing the equivalent environmental conditions, as well as locations with decreasing degrees of environmental similarity. 
(a)

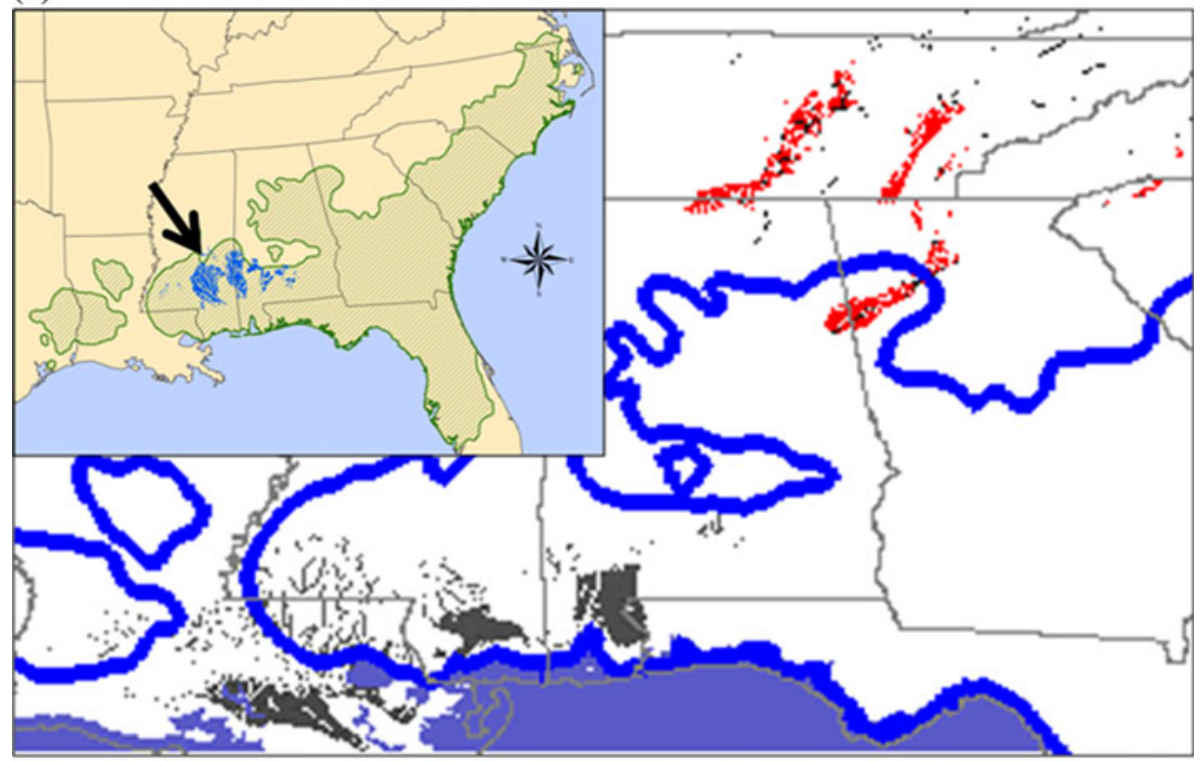

(b)

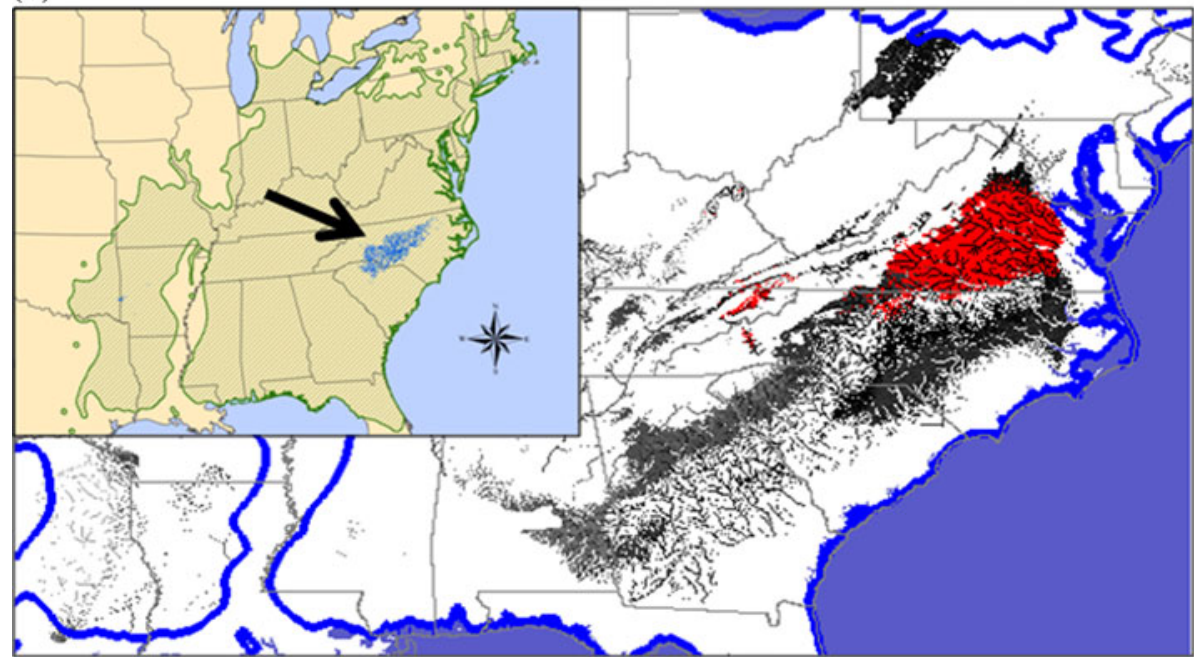

Fig. 4 Forward projections of suitable environmental locations in 2050, under Hadley B1, for a longleaf pine, Pinus palustris Mill., and b flowering dogwood, Cornus florida L., for the current-time focal ecoregions shown in the insets. Such forward projections answer the question: "If I have seeds from a given location, where can I plant them to best ensure that the trees will be well-adapted in the future?" Red areas are exact habitat matches in 2050 with the focal ecoregion, while decreasingly gray areas have environmental conditions that are decreasingly similar to the focal ecoregion

For longleaf pine, we selected an example future ecoregion immediately north of the current range of the species, in north-central North Carolina, as a potential location for establishing the species (Fig. 5a inset). Areas in current time similar to the 2050 Hadley B1 conditions projected for that future ecoregion were identified to the south of the target ecoregion, along the northern edge of the longleaf range in South Carolina and North 
(a)

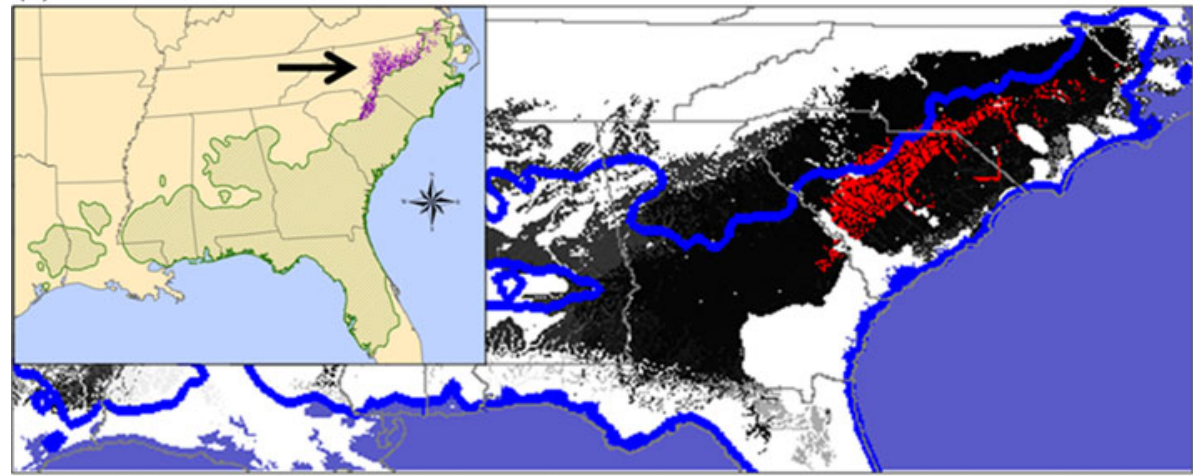

(b)

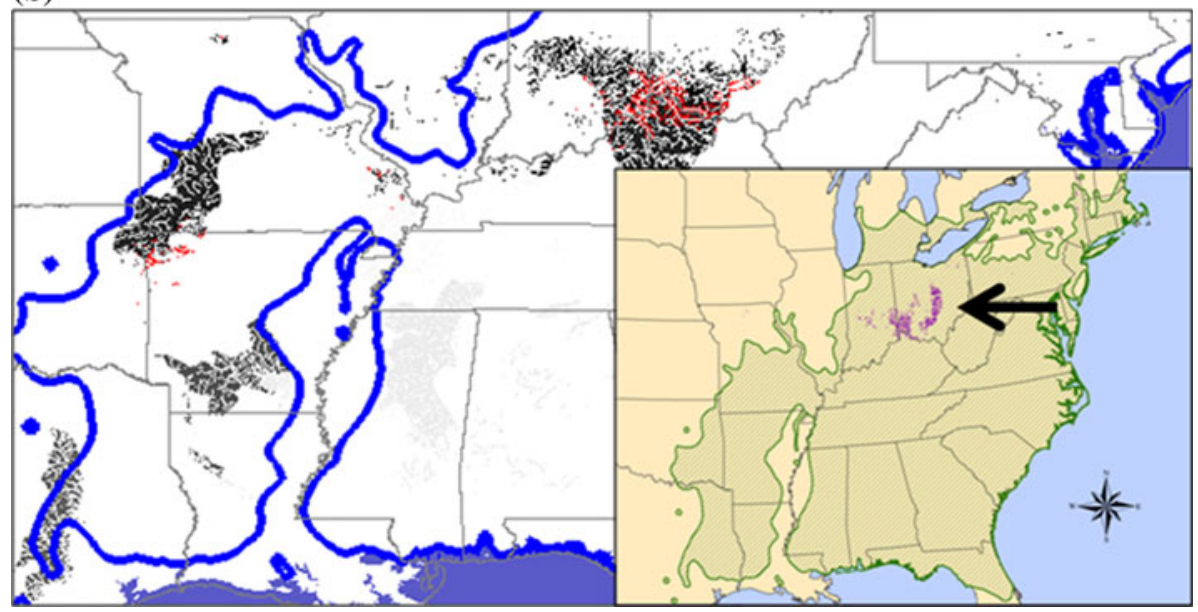

Fig. 5 Reverse projections of suitable environmental locations in current time for a longleaf pine, Pinus palustris Mill., and b flowering dogwood, Cornus florida L., for the Hadley B1 2050 focal ecoregions shown in the insets. Such reverse projections answer the question: "If I want to plant trees in a given location and best ensure those trees will be well-adapted in the future, where do I go to collect the seeds?" Red areas are exact habitat matches in current time with the focal ecoregion, while decreasingly gray areas have environmental conditions that are decreasingly similar to the focal ecoregion

Carolina (Fig. 5a). Areas of non-equivalent, but similar, environmental conditions existed throughout the southeastern United States. For flowering dogwood, we identified an example area in the north-central part of its range as our potential future planting area (Fig. 5b inset). In current time, the best-adapted seed source areas were projected to exist in the same vicinity as the target location, as well as to the southwest in northwestern Arkansas. Areas of lower environmental similarity were identified in areas generally adjacent to the locations identified as environmentally equivalent.

\section{Discussion}

Seed transfer decisions, including those that form the basis of production, restoration, reforestation and afforestation efforts, should account for the potentially serious impacts of 
climate change on the adaptedness of trees and other plants to the locations where they are established. Specifically, static seed transfer zones must become more dynamic as the chances decrease that plant populations remain well-adapted to their local conditions (Vitt et al. 2010; Kramer and Havens 2009).

Integrating changing climate conditions into seed transfer decision-making, however, will represent a major challenge, particularly when little is known about existing patterns of adaptive variation across the range of a species. We suggest that a reasonable seed transfer strategy for such species incorporates ecoregions that are quantitatively defined in current time, and are then projected into the future based on climate change projections. This approach objectively defines ecologically similar areas, both currently and in the future, to a given plant establishment site or to a plant source location, irrespective of geographic distance from the original seed source location or planting site. Although generally more complicated than determining geographic distance between seed source and planting site, site similarity based on large-scale environmental factors including climate, geology and geomorphology is a more useful predictor of potential seed source adaptedness to a restoration site (McKay et al. 2005; Vander Mijnsbrugge et al. 2010).

This approach may appear contrary to the argument that locally sourced seed should, in most cases, be used in habitat restoration and reforestation work because plants collected near a restoration site should be better adapted to that location (Lesica and Allendorf 1999; Sackville Hamilton 2001), a perspective that has been integrated into government restoration policy in some places (Smith et al. 2009). While this has been confirmed for some forest tree species (Johnson et al. 2004, 2010a), population structure and transplant studies suggest that the distance between populations is not always the best indicator of population genetic similarity (Hufford and Mazer 2003). Genetic distance between populations is often more closely correlated with environmental distance than with geographic distance (Montalvo and Ellstrand 2000), so matching habitats may be more important than matching local seed sources that may come from differing local habitats (Wilkinson 2001). In other words, the most appropriate material to ensure restoration success will likely be from sources most closely matching the climatic and edaphic conditions of the restoration site, regardless of the geographic distance to that source (Vitt et al. 2010; Broadhurst et al. 2008), although seed transfer across very long distances should always be undertaken with much caution, whether based on our seed transfer ecoregions or other model results, because of the possibility that critical environmental characteristics that vary greatly across large distances are not adequately reflected in the results. Insisting on the exclusive use of local material, on the other hand, may consign a restoration or reforestation project to a "genetic dead end" that does not allow for the rapid adaptation to changed circumstances that may be needed if climate change scenarios proceed as predicted (Harris et al. 2006).

This seems to be an issue of seed zone resolution: Seed zone delineations are generally artificial constructs drawn with distinct boundaries and at very coarse resolution for administrative and seed inventory convenience, so they often fail to consider the recurrence of similar genotypes in similar environments separated by dissimilar environments (Johnson et al. 2004). Seed zones with finer resolution, such as the $4 \mathrm{~km}^{2}$ resolution at which our analysis is conducted, reflect the reality that environmental variation across the landscape is often highly heterogeneous. Within a climate zone, for example, there may be strong but localized selection gradients in the edaphic environment, such as droughtsusceptible and serpentine soil (McKay et al. 2005). Because our quantitative ecoregions are derived from the environmental distance among $4 \mathrm{~km}^{2}$ cells, rather than on geographic distance or spatial contiguity, the zones can be somewhat fragmented and discontinuous (Figs. 2a, 3a). These quantitative seed transfer ecoregions, however, allow for more robust 
habitat matching, or collection of plant materials from sites with similar environmental characteristics to the location being restored or reforested (O'Brien et al. 2007).

Given the expected environmental changes associated with changing climate, it will be necessary to predict the future climate conditions of a site to assess dynamically a seed source's potential for adaptedness to that location. One established approach is to combine estimates of species' bioclimatic envelopes with downscaled products of climate modeling, which can predict the future spatial extent of those bioclimatic envelopes and, therefore, determine where species' ranges might exist, disappear, move, grow or shrink under changed climatic conditions (Harris et al. 2006). We take an additional step by separately projecting the future locations of environmentally similar portions of a species' range, which, in the absence of other information, we assume to be associated with differences in adaptive variation across the range of the species (Figs. 2a, 3a). We next depict which areas, beyond a specific ecoregion, are most environmentally similar to that ecoregion, whether projecting into the future based on a current seed location (Fig. 4), or projecting backward from a location at which we want to plant trees that will be well-adapted to future conditions (Fig. 5). seed transfer ecoregions, as defined here, are bidirectional or transitive in time. That is, the same set of identical and highly similar ecoregions will be obtained whether forecasting or back-casting. It is critical, however, to underscore the considerable uncertainty that exists about the direction and extent of potential climate change (Harris et al. 2006). The results we present here are limited to a single GCM/ emissions scenario combination for a single point in time, to demonstrate the potential utility of seed transfer ecoregions in the context of climate change. Restoration planners and seed managers should consider the projections from multiple GCM-emissions scenario combinations when they make seed transfer decisions, and should conduct small-scale test transfers to validate the projections.

\section{Applying quantitative ecoregions as seed zones}

These tools for seed transfer decision-making are not a substitute for detailed, long-term studies quantifying the relationships between adaptive variation and environmental variation within species of interest. Data from such efforts have been considered the "gold standard" for matching material to site (Jones 2005). Researchers have employed several innovative spatial techniques to relate adaptive variation data to the landscape (e.g., Crowe and Parker 2005; Wu and Ying 2004; Hamann et al. 2000, 2011). Often, trait variation is summarized using principal components analysis (PCA), with leading principal components axes regressed against environmental variables and the resulting models used to map trait variation on the landscape (e.g., Parker 2000; Johnson et al. 2010b; Rehfeldt and Jaquish 2010; Horning et al. 2010). The use of a more direct spatial clustering approach, similar to our analysis but using adaptive trait variation data, is not unprecedented in the delineation of seed zones: Working with hybrid spruce in British Columbia, O'Neill and Aitken (2004) clustered a large array of predicted adaptive values from grid cells into a predetermined number of breeding zone clusters. Each cell's cluster assignment was then mapped to delineate breeding zone boundaries; a regional maladaptation index within these zones was found to be less than when zones were defined based on equal elevational or adaptive-value widths. A hybrid approach that combines the mapping of such clustered groups of genetic traits with clustered groups of environmental characteristics may represent a meaningful future direction in the development of seed transfer zones.

In the absence of such associations between genetic and environmental data, seed collection zones based on ecologically similar areas can be used as a meaningful guide 
when combined with careful consideration of the taxonomic and floristic literature (Montalvo and Ellstrand 2000). Specifically, it is important that seed transfer strategies account for such life-history characteristics as mating systems, pollination vectors and seed dispersal regimes (Hufford and Mazer 2003), and for environmental generalist versus specialist status (Johnson et al. 2004). Our ecoregion similarity output would enable restoration planners and seed source managers to refine their collection and planting strategies based on these species-specific life history traits. Flowering dogwood, for example, might be more adequately adapted to areas that are lighter gray (less environmentally similar) on our ecoregion similarity maps (Figs. 4a, 5b) because its seeds can be dispersed long distances by birds (McLemore 1990) and because it is highly outcrossed (Apsit et al. 2002); highly outcrossing taxa are less likely to represent ecotypic differentiation as a result of the homogenizing effect of gene flow (Hufford and Mazer 2003). Longleaf pine, meanwhile, might be considered adequately adapted to areas that are darker gray because its wind-dispersed seed is not as likely to move long distances (Boyer 1990).

A significant challenge posed by climate change to restoration and ecosystem management in general is the considerable uncertainty about the direction and extent of potential change (Harris et al. 2006). Additionally, new seed transfer recommendations need to balance anticipated future conditions with the fact that successful seedling establishment occurs under existing conditions, even though they may be transient. Seed transferred too far in anticipation of future warming may suffer excessive mortality during establishment, but ignoring climate predictions could result in the planting of local seed sources that may not be adequately competitive (Bower and Aitken 2008). Our quantitative ecoregion outputs could assist in the implementation of two strategies to address these challenges. The first would be to unidirectionally transfer seed from a given location toward colder climate conditions under a floating seed transfer model (Bower and Aitken 2008), with the expectation that the transfer location would become warmer in the future and therefore more similar to the seed source location. Our ecoregion similarity maps could be used to identify currently colder locations that are still adequately similar to the seed source location.

The second strategy, called "composite provenancing," would differentially sample populations at various distances from a focal site, including distant but ecogeographically matched sources; while this approach may lead to some seedling failure if the more distant material is maladapted, it would facilitate the production of new gene combinations potentially able to respond to environmental changes (Broadhurst et al. 2008). For trees, however, it could require two or more decades to produce these genotypes given the length of time to reach reproductive maturity. Again, we propose that our ecoregion similarity maps could provide a measure of environmental distance used to structure this sampling approach.

In all cases, the determination of seed transfer zones, guidelines and recommendations need to incorporate knowledge and experience from foresters, forest managers, seed planners and scientists to ensure the functionality and practicability of the zones or guidelines for a given species (Ying and Yanchuk 2006). That is the case with the ecoregions we propose as seed transfer tools, despite their quantitative nature. This is particularly true in light of the scale of the results; the seed transfer ecoregions may identify general areas likely to encompass the appropriate environmental conditions, but practitioners will need to identify the specific sites containing those conditions. Additionally, the monitoring of restored populations can provide insights into demography, habitat requirements and other factors that determine the success of the populations (Vitt et al. 2010), and can improve the success of ecological restoration projects as well as our understanding of patterns of adaptive genetic variation within plant species (O’Brien et al. 2007). 
Our quantitatively defined seed transfer ecoregions can be used for a variety of additional uses for which other ecosystem delineations have been applied, including structuring seed sampling efforts for gene conservation (Vitt et al. 2010), surveying genetic variation on the landscape when no relevant genetic data exist for a given species of interest (Horning et al. 2010), and identifying seed sources for inclusion in provenance trials to examine broad-scale genetic differences (Johnson et al. 2004). Additionally, the global nature of our quantitatively defined ecoregions allows for the identification of any location in the world that may be a suitable location for plant establishment. This tool could have several applications, including assisting in the identification of intra-continental plant refuge translocations, which have proved an important conservation tool to help species escape diseases and insects driving them toward extinction in their native range (Vitt et al. 2010; Jetton et al. 2010). Our analysis identified locations in southeastern Paraguay and extreme southern Brazil that belong to the same ecoregions as those in which longleaf pine currently exists in the southeastern United States; under the Hadley B1 projection for 2050, suitable locations were predicted to continue to exist in these regions (results not shown). For flowering dogwood, our analysis identified small areas in eastern Australia, western Kenya, southern Brazil, and the nation of Georgia containing current ecoregions for the species. In 2050, these locations were projected to remain suitable, joined by additional locations in northeastern Italy, north-central Austria, and Slovenia.

\section{Conclusions}

The development and application of seed transfer zones for species of restoration value is an area that needs significant focus, particularly in light of rapidly changing climates (Kramer and Havens 2009; Harris et al. 2006), given that access to high quality and appropriately sourced germplasm is necessary to improve planting success and to ensure that new populations become functional, self-sustaining and resilient to environmental challenges (Broadhurst et al. 2008). Our global system of 30,000 quantitatively defined ecoregions can assist in such seed transfer decision-making for production, restoration, reforestation and afforestation efforts, while taking into account expected climate change. A feature of particular value may be the depiction of ecoregion similarity, both when identifying a planting location at which an existing seed source is most likely to be welladapted under climate change, or finding a seed source that is likely to provide welladapted seed into the future for a known planting site. This quantitative approach fits well with the risk-minimization philosophy for seed zone and seed transfer guideline development (Hamann et al. 2011); the farther the seed transfer along the similarity gradient, the greater the risk of maladaptation. This assumes that trees and other plants are optimally adapted to the environments in which they occur, which is not always the case (Wu and Ying 2004; Mangold and Libby 1978), but this seems a reasonable assumption in the absence of adaptive genetic information across the range of a species.

Acknowledgments We thank Frank Koch for assistance with the Forest Inventory and Analysis data and Steve Norman for helpful suggestions. Forrest Hoffman was instrumental in developing the parallel MSTC code and ran the clustering analysis. Barry Baker and Chris Zganjar prepared the input data sets used for the MSTC process. This work was supported in part by the Eastern Environmental Threat Assessment Center; by the Forest Health Monitoring program of the United States Department of Agriculture (USDA) Forest Service; and by Research Joint Venture Agreements 10-JV-11330146-049 and 11-JV-11330146-090 between the USDA Forest Service, Southern Research Station, and North Carolina State University. 


\section{References}

Apsit VJ, Dyer RJ, Sork VL (2002) Patterns of mating in an insect-pollinated tree species in the Missouri Ozark Forest Ecosystem Project (MOFEP). In: Shifley SR, Kabrick JM (eds) Second Missouri Ozark Forest Ecosystem Project Ecosystem symposium: post-treatment results of the landscape experiment, general technical report NC-227. USDA Forest Service, North Central Experiment Station, St. Paul, pp 212-226

Baker B, Diaz H, Hargrove W, Hoffman F (2010) Use of the Koppen-Trewartha climate classification to evaluate climatic refugia in statistically derived ecoregions for the People's Republic of China. Clim Change 98(1-2):113-131. doi:10.1007/s10584-009-9622-2

Bower AD, Aitken SN (2008) Ecological genetics and seed transfer guidelines for Pinus albicaulis (Pinaceae). Am J Bot 95:66-76

Boyer WD (1990) Longleaf pine. In: Burns RM, Honkala BH (eds) Silvics of North America: 1. Conifers, vol 1. Agricultural handbook 654. U.S. Department of Agriculture, Forest Service, Washington, DC

Broadhurst LM, Lowe A, Coates DJ, Cunningham SA, McDonald M, Vesk PA, Yates C (2008) Seed supply for broadscale restoration: maximizing evolutionary potential. Evol Appl 1(4):587-597. doi:10.1111/ j.1752-4571.2008.00045.x

Carr DE, Banas LE (2000) Dogwood anthracnose (Discula destructiva): effects of and consequences for host (Cornus florida) demography. Am Midl Nat 143(1):169-177. doi:10.1674/0003-0031(2000)

Crowe KA, Parker WH (2005) Provisional breeding zone determination modeled as a maximal covering location problem. Can J For Res (Revue Canadienne De Recherche Forestiere) 35(5):1173-1182. doi: 10.1139/x05-041

Fitzpatrick MC, Hargrove WW (2009) The projection of species distribution models and the problem of non-analog climate. Biodivers Conserv 18(8):2255-2261. doi:10.1007/s10531-009-9584-8

Gilliam FS, Platt WJ (2006) Conservation and restoration of the Pinus palustris ecosystem. Appl Veg Sci 9(1):7-10. doi:10.1658/1402-2001(2006)

Global Soil Data Task Group (2000) Global gridded surfaces of selected soil characteristics (International Geosphere-Biosphere Programme-Data and Information System [IGBP-DIS]). Oak Ridge National Laboratory Distributed Active Archive Center, Oak Ridge. doi:10.3334/ORNLDAAC/569

Griffith GE, Omernik JM, McGinley M (2008) Ecoregions of the United States-Level IV (EPA). Environmental Information Coalition, National Council for Science and the Environment. http://www. eoearth.org/article/Ecoregions_of_the_United_States-Level_IV_(EPA). Accessed 24 Aug 2011

Hamann A, Koshy MP, Namkoong G, Ying CC (2000) Genotype x environment interactions in Alnus rubra: developing seed zones and seed-transfer guidelines with spatial statistics and GIS. For Ecol Manag 136(1-3):107-119. doi:10.1016/s0378-1127(99)00284-4

Hamann A, Gylander T, Chen PY (2011) Developing seed zones and transfer guidelines with multivariate regression trees. Tree Genet Genomes 7(2):399-408. doi:10.1007/s11295-010-0341-7

Hargrove WW, Hoffman FM (2003) An analytical assessment tool for predicting changes in a species distribution map following changes in environmental conditions. In: Parks BO, Clark KM, Crane MP (eds) Proceedings of the 4th international conference on integrating GIS and environmental modeling (GIS/EM4): problems, prospects and research needs, September 2-8, 2000, Banff, Alberta, Canada. Cooperative Institute for Research in Environmental Sciences; NOAA National Geophysical Data Center, Ecosystem Informatics; and US Geological Survey, Center for Biological Informatics

Hargrove WW, Hoffman FM (2005) Potential of multivariate quantitative methods for delineation and visualization of ecoregions. Environ Manage 34 (Suppl. 1):S39-S60

Hargrove WW, Hoffman FM, Hessburg PF (2006) Mapcurves: a quantitative method for comparing categorical maps. J Geogr Syst 8(2):187-208. doi:10.1007/s10109-006-0025-x

Harris JA, Hobbs RJ, Higgs E, Aronson J (2006) Ecological restoration and global climate change. Restor Ecol 14(2):170-176. doi:10.1111/j.1526-100X.2006.00136.x

Hijmans RJ, Cameron SE, Parra JL, Jones PG, Jarvis A (2005) Very high resolution interpolated climate surfaces for global land areas. Int J Climatol 25(15):1965-1978. doi:10.1002/joc.1276

Hoffman FM, Hargrove WW, Erickson DJ, Oglesby RJ (2005) Using clustered climate regimes to analyze and compare predictions from fully coupled general circulation models. Earth Interact 9(10):1-27

Holzmueller E, Jose S, Jenkins M, Camp A, Long A (2006) Dogwood anthracnose in eastern hardwood forests: what is known and what can be done? J For 104(1):21-26

Horning ME, McGovern TR, Darris DC, Mandel NL, Johnson R (2010) Genecology of Holodiscus discolor (Rosaceae) in the Pacific Northwest, USA. Restor Ecol 18(2):235-243. doi:10.1111/j.1526-100X. 2008.00441.x

Hufford KM, Mazer SJ (2003) Plant ecotypes: genetic differentiation in the age of ecological restoration. Trends Ecol Evol 18(3):147-155. doi:10.1016/s0169-5347(03)00002-8 
Jetton RM, Whittier WA, Dvorak WS, Rhea JR (2010) Status of gene conservation efforts for eastern and Carolina hemlock in the eastern United States. In: Onken B, Reardon R (eds) Fifth Symposium on Hemlock Woolly Adelgid in the Eastern United States, Asheville, North Carolina, 2010. USDA Forest Service, Forest Health Technology Enterprise Team, Morgantown, pp 93-99

Johnson GR, Sorensen FC, St Clair JB, Cronn RC (2004) Pacific Northwest forest tree seed zones: a template for native plants? Nativ Plants J 5(2):131-140

Johnson GR, Stritch L, Olwell P, Lambert S, Horning ME, Cronn RC (2010a) What are the best seed sources for ecosystem restoration on BLM and USFS lands? Nativ Plants J 11(2):117-131

Johnson RC, Erickson VJ, Mandel NL, St Clair JB, Vance-Borland KW (2010b) Mapping genetic variation and seed zones for Bromus carinatus in the Blue Mountains of eastern Oregon. USA Bot 88(8): 725-736. doi:10.1139/b10-047

Jones TA (2005) Genetic principles and the use of native seeds: just the FAQs, please, just the FAQs. Nativ Plants J 6(1):14-24

Kramer AT, Havens K (2009) Plant conservation genetics in a changing world. Trends Plant Sci 14(11):599-607. doi:10.1016/j.tplants.2009.08.005

Lesica P, Allendorf FW (1999) Ecological genetics and the restoration of plant communities: mix or match? Restor Ecol 7(1):42-50. doi:10.1046/j.1526-100X.1999.07105.x

Little EL (1971) Atlas of United States trees, vol 1. Conifers and Important Hardwoods, Washington, DC

Lugo AE, Brown SL, Dodson R, Smith TS, Shugart HH (1999) The Holdridge life zones of the conterminous United States in relation to ecosystem mapping. J Biogeogr 26(5):1025-1038. doi:10.1046/j. 1365-2699.1999.00329.x

Malaval S, Lauga B, Regnault-Roger C, Largier G (2010) Combined definition of seed transfer guidelines for ecological restoration in the French Pyrenees. Appl Veg Sci 13(1):113-124. doi:10.1111/j.1654109X.2009.01055.x

Manel S, Poncet BN, Legendre P, Gugerli F, Holderegger R (2010) Common factors drive adaptive genetic variation at different spatial scales in Arabis alpina. Mol Ecol 19(17):3824-3835. doi:10.1111/j.1365294X.2010.04716.x

Mangold RD, Libby WJ (1978) Model for reforestation with optimal and suboptimal tree populations. Silvae Genet 27(2):66-68

McKay JK, Christian CE, Harrison S, Rice KJ (2005) "How local is local?"-a review of practical and conceptual issues in the genetics of restoration. Restor Ecol 13(3):432-440. doi:10.1111/j.1526100X.2005.00058.x

McLemore BC (1990) Flowering dogwood. In: Burns RM, Honkala BH (eds) Silvics of North America: 2. Hardwoods, vol 2. Agricultural Handbook 654. U.S. Department of Agriculture, Forest Service, Washington, DC

Miller SA, Bartow A, Gisler M, Ward K, Young AS, Kaye TN (2010) Can an ecoregion serve as a seed transfer zone? Evidence from a common garden study with five native species. Restor Ecol 19:268-276. doi:10.1111/j.1526-100X.2010.00702.x

Montalvo AM, Ellstrand NC (2000) Transplantation of the subshrub Lotus scoparius: testing the home-site advantage hypothesis. Conserv Biol 14(4):1034-1045. doi:10.1046/j.1523-1739.2000.99250.x

Moore ID, Grayson RB, Ladson AR (1991) Digital terrain modeling: a review of hydrological, geomorphological, and biological applications. Hydrol Process 5(1):3-30. doi:10.1002/hyp.3360050103

Neilson RP (1995) A model for predicting continental-scale vegetation distribution and water balance. Ecol Appl 5(2):362-385. doi:10.2307/1942028

O'Brien EK, Mazanec RA, Krauss SL (2007) Provenance variation of ecologically important traits of forest trees: implications for restoration. J Appl Ecol 44(3):583-593. doi:10.1111/j.1365-2664.2007.01313.x

O'Neill GA, Aitken SN (2004) Area-based breeding zones to minimize maladaptation. Can J For Res (Revue Canadienne De Recherche Forestiere) 34(3):695-704. doi:10.1139/x03-227

Parker WH (1992) Focal point seed zones: site-specific seed zone delineation using geographic information systems. Can J For Res (Revue Canadienne De Recherche Forestiere) 22(2):267-271. doi: $10.1139 /$ X92-035

Parker WH (2000) Rates of change of adaptive variation in Picea mariana visualized by GIS using a differential systematic coefficient. New For 20(3):259-276. doi:10.1023/a:1006736019650

Parmesan C, Yohe G (2003) A globally coherent fingerprint of climate change impacts across natural systems. Nature 421(6918):37-42

Persson B (1998) Will climate change affect the optimal choice of Pinus silvestris provenances? Silva Fennica 32(2):121-128

Pojar J, Klinka K, Meidinger DV (1987) Biogeoclimatic ecosystem classification in British Columbia. Forest Ecol Manag 22(1-2):119-154. doi:10.1016/0378-1127(87)90100-9 
Potter KM, Hargrove WW, Koch FH (2010) Predicting climate change extirpation risk for central and southern Appalachian forest tree species. In: Proceedings from the conference on ecology and management of high-elevation forests of the Central and Southern Appalachian Mountains, Snowshoe, West Virginia, May 14-15, 2009. USDA Forest Service, Northern Research Station, Newtown Square

Prentice IC, Cramer W, Harrison SP, Leemans R, Monserud RA, Solomon AM (1992) A global biome model based on plant physiology and dominance, soil properties and climate. J Biogeogr 19(2): 117-134. doi: $10.2307 / 2845499$

Rehfeldt GE, Jaquish BC (2010) Ecological impacts and management strategies for western larch in the face of climate-change. Mitig Adapt Strateg Glob Change 15(3):283-306. doi:10.1007/s11027-010-9217-2

Rehfeldt GE, Ying CC, Spittlehouse DL, Hamilton DA (1999) Genetic responses to climate in Pinus contorta: Niche breadth, climate change, and reforestation. Ecol Monogr 69(3):375-407

Rehfeldt GE, Wykoff WR, Ying CC (2001) Physiologic plasticity, evolution, and impacts of a changing climate on Pinus contorta. Clim Change 50(3):355-376

Root TL, Price JT, Hall KR, Schneider SH, Rosenzweig C, Pounds JA (2003) Fingerprints of global warming on wild animals and plants. Nature 421(6918):57-60. doi:10.1038/nature01333

Sackville Hamilton NR (2001) Is local provenance important in habitat creation? A reply. J Appl Ecol 38(6):1374-1376

Saxon E, Baker B, Hargrove W, Hoffman F, Zganjar C (2005) Mapping environments at risk under different global climate change scenarios. Ecol Lett 8(1):53-60. doi:10.1111/j.1461-0248.2004.00694.x

Schmidtling RC (1994) Use of provenance tests to predict response to climatic change: loblolly pine and Norway spruce. Tree Physiol 14(7-9):805-817

Schmidtling RC (2001) Southern pine seed sources. United State Department of Agriculture, Forest Service, Southern Research Station, Asheville

Smith WB (2002) Forest inventory and analysis: a national inventory and monitoring program. Environ Pollut 116:S233-S242

Smith BM, Diaz A, Daniels R, Winder L, Holland JM (2009) Regional and ecotype traits in Lotus corniculatus L., with reference to restoration ecology. Restor Ecol 17(1):12-23. doi:10.1111/j.1526-100X. 2007.00327.x

Thomson AM, Crowe KA, Parker WH (2010) Optimal white spruce breeding zones for Ontario under current and future climates. Can J For Res (Revue Canadienne De Recherche Forestiere) 40(8): 1576-1587. doi:10.1139/x10-112

United States Department of Agriculture Forest Service (2008) Forest inventory and analysis national core field guide, version 4.0. USDA Forest Service, Forest Inventory and Analysis National Office. www.fia.fs.fed.us/library/field-guides-methods-proc. Accessed 20 Feb 2008

Van Lear DH, Carroll WD, Kapeluck PR, Johnson R (2005) History and restoration of the longleaf pinegrassland ecosystem: implications for species at risk. For Ecol Manag 211(1-2):150-165. doi: 10.1016/j.foreco.2005.02.014

Vander Mijnsbrugge K, Bischoff A, Smith B (2010) A question of origin: where and how to collect seed for ecological restoration. Basic Appl Ecol 11(4):300-311. doi:10.1016/j.baae.2009.09.002

Vitt P, Havens K, Kramer AT, Sollenberger D, Yates E (2010) Assisted migration of plants: changes in latitudes, changes in attitudes. Biol Conserv 143(1):18-27. doi:10.1016/j.biocon.2009.08.015

Vogel KP, Schmer MR, Mitchell RB (2005) Plant adaptation regions: ecological and climatic classification of plant materials. Rangel Ecol Manag 58(3):315-319. doi:10.2111/1551-5028(2005)

Wilkinson DM (2001) Is local provenance important in habitat creation? J Appl Ecol 38(6):1371-1373. doi: 10.1046/j.0021-8901.2001.00669.x

Williams CE, Moriarity WJ (1999) Occurrence of flowering dogwood (Cornus florida L.), and mortality by dogwood anthracnose (Discula destructiva Redlin), on the northern Allegheny Plateau. J Torrey Bot Soc 126(4):313-319. doi:10.2307/2997315

Wilson BL, Darris DC, Johnson R, Horning ME, Kuykendall K (2008) Seed transfer zones for a native grass (Festuca roemeri): genecological evidence. Nativ Plants J 9(3):287-302

Woodall CW, Oswalt CM, Westfall JA, Perry CH, Nelson MD, Finley AO (2009) An indicator of tree migration in forests of the eastern United States. For Ecol Manag 257(5):1434-1444. doi: 10.1016/j.foreco.2008.12.013

Wu HX, Ying CC (2004) Geographic pattern of local optimality in natural populations of lodgepole pine. For Ecol Manag 194(1-3):177-198. doi:10.1016/j.foreco.2004.02.017

Wu HX, Ying CC, Ju HB (2005) Predicting site productivity and pest hazard in lodgepole pine using biogeoclimatic system and geographic variables in British Columbia. Ann For Sci 62(1):31-42. doi: 10.1051/forest:2004089

Ying CC, Yanchuk AD (2006) The development of British Columbia's tree seed transfer guidelines: purpose, concept, methodology, and implementation. For Ecol Manag 227(1-2):1-13 